\title{
PROFESSOR R. S. TROUP
}

(Late Director, Imperial Forestry Institute)

We regret to announce the death of Professor Robert Scott Troup, C.M.G., C.I.E., F.R.S., Professor of Forestry in the University of Oxford, which occurred at Oxford on Sunday, October 1.

Professor Troup, who was 64 years of age, was educated at the Gymnasium, Aberdeen, and the University of Aberdeen. Later he entered Coopers Hill College, Egham, which prepared engineering forestry students for the Colonial services. He joined the I.F.S. in 1897 and was posted to Burma; eight years later, he was appointed Forest Economist at the new Forest Research Institute at Dehra Dun, where, in 1915, he was promoted to be Assistant Inspector of Indian Forests.

During the war of 1914-18 he served as Controller of Timber Supplies in India.

In 1920 Professor Troup was selected for the Chair of Forestry at Oxford and was elected a Fellow of St. John's College. In 1924 he was appointed Director of the Imperial Forestry Institute, a post he retained until 1935 when he was succeeded by Mr. Oliphant of the Malayan Forestry Service

Professor Troup was a well-known writer on silvicultural sub: jects and several of his books, especially on Indian timbers, are widely recognised as authoritative works.

He was married in 1901 and leaves a widow, two sons and a daughter. The funeral took place privately on Tuesday, October 3.

He attended the British Empire Forestry Conference in Canada in 1923 and his many friends in Canada will hear of his death with sincere regret. 